\title{
RELIGIOUS MODERATION IN INDONESIAN HIGHER EDUCATIONS: Literature Review
}

\author{
Benny Afwadzi and Miski \\ Universitas Islam Negeri Maulana Malik Ibrahim Malang, Indonesia \\ E-mail: afwadzi@pai.uin-malang.ac.id
}

\begin{abstract}
This article is an attempt to review various studies on religious moderation or moderate Islam among students in the higher educations in Indonesia. It is written as prompted by the incompleteness of various studies regarding the same theme. Specifically, the main issue concerns how the studies on this theme emerge and continue to develop. It is then formulated into three main issues: how the construction of religious moderation is developed in Indonesia; how it is formulated into strategic policies in the higher education context; and how relevant the religious moderation program in the higher educations in Indonesia in the context of contemporary life is. By using a qualitative-library approach and content analysis, the finding shows that religious moderation or moderate Islam, which is believed to be Islam itself, is a moderate religious understanding and attitude. It is not extreme, is not either left or right; and is interpreted with four indicators: national commitment, tolerance, nonviolence, and accommodative to local culture. From this stance, Indonesian Islamic moderation researchers propose various recommendations to be applied to specific education policies. In the practice, these recommendations are academically applied, both in formal and informal ways, according to the situations and conditions of the related higher education context. Moreover, recent studies have shown that several counter-radicalism strategies, through the moderation implemented in various higher educations, seem relevant in the higher education context.
\end{abstract}


Tulisan ini merupakan upaya mereview berbagai kajian tentang moderasi beragama atau Islam moderat di kalangan mahasiswa di lingkungan perguruan tinggi Indonesia. Tulisan ini berpijak pada kenyataan ketidakutuhan berbagai kajian dalam tema tersebut. Secara spesifik, isu utama yang diangkat adalah bagaimana kajian-kajian dalam tema tersebut muncul dan terus berkembang. Isu utama ini kemudian diformulasikan ke dalam tiga persoalan utama: bagaimana konstruksi moderasi beragama yang dikembangkan di Indonesia; bagaimana ia diformulasikan ke dalam kebijakan yang strategis di lingkungan perguruan tinggi; dan bagaimana relevansi program moderasi beragama di lingkungan perguruan tinggi Indonesia dalam konteks kehidupan kontemporer. Dengan menggunakan pendekatan kualitatif-kepustakaan dan analisis isi, kajian ini menunjukkan bahwa moderasi beragama atau Islam moderat, yang diyakini sebagai Islam itu sendiri, adalah pemahaman dan sikap keagamaan yang pertengahan, tidak ektrem, baik kiri maupun kanan; dan ditafsirkan dengan empat indikator: komitmen kebangsaan, toleransi, anti kekerasan, dan akomodatif terhadap budaya lokal. Dari pijakan ini, muncul berbagai rekomendasi dari para pengkaji moderasi Islam Indonesia untuk diaplikasikan ke dalam kebijakan-kebijakan khusus dunia pendidikan. Pada praktiknya, rekomendasi tersebut diaplikasikan, baik secara formal akademik maupun informal, sesuai dengan situasi dan kondisi masing-masing di lingkungan perguruan tinggi terkait. Lebih dari itu, kajian terkini menunjukkan bahwa beberapa strategi kontra radikalisme melalui moderatisasi yang diimplementasikan di berbagai perguruan tinggi tampak relevan di lingkungan pendidikan tinggi.

Keywords: higher education; radicalism; religious moderation

Received: October 5, 2021; Accepted: November 15, 2021

\section{Introduction}

The effort to make religious moderation or moderate Islam to be on the mainstream side has frequently been expressed by various levels of society (Afwadzi 2020; Afwadzi and Miski 2020; Djamil 2011; Kementerian Agama RI 2019; Kementerian Agama RI 2012; Shihab 2020). In 2015, the Indonesian Ulama Council (MUI) clearly and firmly campaigned for moderate Islam in order to create a harmonious life within the nation and state. In the same year to the following years, until now, the same themes and topics have been progressively campaigned in various religious and 
social activities. The massive campaign of religious moderation or moderate Islam is intertwined with the spread of radical-terror movements executed by many individuals who have various motives and goals. In this case, religious moderation is believed to be able to block the movements that may actually harm Islam (Mohammad 2018; Prasetiawati 2017). However, in various parts of the world, conflicts continue to emerge and cause a concern. This conflict becomes more obviously seen in several countries in the Middle East. The existence of extremism and terrorism movements, such as the Islamic State of Iraq and Shiria (ISIS) is a factual example of the latest conflict widely spread to various parts of the world (Osman and Arosoaie 2020; Pashentsev and Bazarkina 2021). Tahir even emphasized that the ISIS movement has also penetrated into higher educations in Indonesia as confirmed in his research (Tahir 2015). This fact triggers a main question, "Can religious moderation be the answer and solution?" It also includes its relation to other conflicts that have not subsided for hundreds of years like the Shî‘a-Sunnî conflict.

$\mathrm{Up}$ to the present day, the studies on religious moderation tend to focus on three main issues. First, the studies specifically explored on how the Quran and hadith describe religious moderation and how the main messages of moderate Islam explained in both sources are believed to be relevant to the current situation and conditions (M. K. Arif 2020; AshShallabi 2020; Kementerian Agama RI 2012; Shihab 2020). Second, those that focused on the thoughts of the experts regarding religious moderation. There are several figures whose works or ideas are relatively chosen as references. Some of them are Gus Dur or Abdurrahman Wahid, Quraish Shihab, Ahmad Muwafiq, Ahmad Syafi'i Ma'arif, as well as foreign figures with various scientific specializations, who are categorized as classic, medieval, and modern-contemporary figures. In addition, they also focused on socio-religious organizations, such as Nahdlatul Ulama (NU) and Muhammadiyah (S. Arif 2020; Darajat 2017; Davids 2017; Hilmy 2013; Nurdin et al. 2019; Salik 2019; Suhaimi and Raudhonah 2020; Suharto 2014; Ulinnuha and Nafisah 2020). Third, about the studies on how religious moderation is applied in a special policy and how related parties, including the higher educations in Indonesia, respond to it. (Hadziq 2019; Haryanto 2018; Paradikma 2019; Shifiyuddin 2019). Apart from the tendency of problem presented in this study, it principally emphasizes on the assumption of the importance of setting moderate Islam as a paradigm of thinking and behaving, particularly in a multicultural society. 
Despite the fact that there are many studies on religious moderation in higher educations in Indonesia, there is one thing that seems to have received no attention: how do these studies reconstruct other studies that have the same theme? Up to now, the studies on the same theme is nothing more than a literature review. In this case, the study being reviewed is only a tool to differentiate it from other studies. From this tendency, the study of religious moderation in higher education appears to be fragmentary, to be partial, and does not show one complete characteristic. In fact, the integrity of the study covering the same theme will contribute to the accuracy of policies in dealing with the spread of radicalism in the university, the accuracy of teaching methods, and others. Using this basis, an in-depth study that is specifically performed to review the development of studies on the same theme becomes urgent and finds its significance. In this section, there are three essential issues as the focus of the study. First, it is the construction of a religious moderation understanding developed in Indonesia. Second, it is the construction of religious moderation that is formulated into strategic policies in higher educations. Third, it is the relevance of religious moderation programs in the higher educations in Indonesia in the context of contemporary life.

In answering the three questions above, this study used a qualitative and literature approach. Overall, the data obtained are divided into two parts: primary and secondary. The primary data are various recent studies on religious moderation or moderate Islam in the higher educations in Indonesia. Meanwhile, the secondary data are in the form of the studies covering the same theme, but they were conducted in other places other than the higher education settings in Indonesia, and other relevant studies, especially 2010-present. In tracing various previous studies, the author uses several key concepts: moderate Islam in higher education, religious moderation in higher education, and the like. For this case, the data that have been collected are analyzed using the method of content analysis. This method is applied based on several systematic steps: 1) mapping the varied data into numerous classifications according to the questions of the study; 2) carrying out the process of interpreting the data; 3) presenting the results of the interpretation according to the needs of the answers to the questions; and 4) drawing conclusions inductively. 


\section{Radicalism and College Students: An Initial Crossroads}

Conceptually, radicalism always faces the moderatism (Hambali 2010; Wahab 2019; Yunanto 2018). In other words, the problems of radicalism, whether as a choice of attitude or religious thinking/understanding, emerge because it is believed by the followers of the extreme views; whether it is put way to the right or way to the left. Basically, the other view that is more feasible of being judged to be the resistance from radicalism is liberalism. If radicalism puts as a connotation to harsh, tough, rigid, and intolerant understanding, attitudes or actions, and others, then liberalism is considered as the opposite of this understanding and attitude. In some cases, liberalism [religion] is assumed to ignore the existence of religion because it reinforces the role of reason. The existence of this view causes discourse battles. Radical groups label liberal groups as 'the worshipers' of reason, ignore the function of God, deny the sanctity of religious texts, and others. Vice versa, the liberal groups assume the radical group as a group that cannot understand the message of the religion well, cannot optimize the role of reason, is not contextual, is too rigid in performing the religious activity, and so on. This simple description of the contestation clarifies that the discourse on the importance of religious moderation is an alternative effort of mainstreaming between two extreme groups: radicals and liberals.

At the historical level, the end of Suharto era (New Order) was the beginning of a period of massive radicalism in Indonesia. This period became an important period as a marker of the beginning of radicalism discourse. This fact has been presented by many researchers of the Islamic movement in Indonesia so that it becomes the post-Suharto era, and it becomes an inseparable part of the radicalism description in Indonesia (Azca 2013; Bruinessen 2002; Ichwan 2013). After the fall of the New Order's power, and it is shifted to the Reformation period, various extreme and radical ideas began to develop rapidly in Indonesia even though they already existed before. Then, radical organizations were gradually and officially established. Some are even acknowledged by the state, such as the Islamic Defenders Front (FPI) and Hizbut Tahrir Indonesia (HTI).

Before the fall of the New Order, Islamic groups were only identified through mainstream organizations, such as NU (Nahdlatul Ulama) and Muhammadiyah. At that time, not many Islamic movements and organizations showed their existence openly. The New Order's authoritarianism kept these Islamic movements from speaking out. In fact, the New Order government attempted to confine NU, the largest Islamic 
organization in Indonesia, but failed (Barton 2011). However, after Suharto stepped down as the President of Indonesia in 1998, non-mainstream movements began to be instilled and try to take on the religious and social roles in the society. These movements, such as the Islamic Defenders Front (FPI), Hizbut Tahrir Indonesia (HTI), Lasykar Jihad, and the Indonesian Mujahidin Council (MMI) openly disclose their identity to the public. This phenomenon is inseparable from the democratic situation that was developed at this time. In terms of quantity, more religious groups and organizations that tend to be radical have clearly and greatly established after the New Order compared to the previous era (Arifin 2020,14).

The end of Suharto era was a time of uncertainty and the start of political disorders since it was a period of transition towards democracy which was never been implemented properly during the reign of Suharto. In this uncertain period, the political opportunity structure occurred and it was considered as an important factor in the mobilization of various social movements, including radical Islamic movements. According to Azca, there are at least three variants of radicalism that have different orientations in this post-Suharto era, such as Jihadi Islam, Salafi, and Politics. The first variant legalizes violence and acts of terror to achieve its goal that is to create an Islamic government. The second variant deals more with the purification of Islamic teachings and has no interest in the political dimension. The third variant focuses on the struggle for the implementation of Islamic law in the government through a legitimate democratic system (Azca 2013, 17-18).

However, these radical movements could not have suddenly existed without any triggering factors. According to Bruinnessen, the radicalism that flourished in the post-New Order era can be traced back to earlier times through the Darul Islam or the Indonesian Islamic State (NII) movement and the Masyumi Party. The first movement caused a rebellion against the state and wanted to establish an Islamic state by using acts of violence and terror. Meanwhile, the second movement penetrated into the democratic system and fought for Islamic law through general elections (Bruinessen 2002). In this case, referring back to Azca variant, Darul Islam seems to be the embryo of Islam Jihad and Masyumi is the embryo of political Islam. These movements have undergone ups and downs since the 1980s along with the development of global and domestic phenomena that strongly influenced the political-religious context, such as the Iranian 
Revolution in 1979 and the fragmentation of the Indonesian political elite since the late 180s (Bruinessen 2002).

Furthermore, at the university level in Indonesia, the religious movements in the campuses cannot be separated from religious movements or politics from abroad (Haryanto 2018, 9). The Ikhwanul Muslimin (IM) or Muslim Brotherhood is identical with Egypt, Hizbut Tahrir Indonesia (HTI) is identical with Palestine, and the Salafi is identical with Saudi Arabia. According to Haryanto, these three groups generally have the same religious views referring to the concept of Islamic purification, but they differ in the context of political and social views. IM, for example, allows its members to participate in the government, while HTI prohibits any form of political party that runs a democratic system and it obligates a Khilafah system. This striking difference causes IM and HTI not to meet but support each other regarding the issues of sharia legality and Islamic formalism. Likewise, the Salafi group eventually chose to refuse to have contact with IM and HTI because they considered these two groups' critical attitudes toward the government as something that violated the sunnah (Haryanto 2019, 47-48). However, it seems that "the Salafi" that Haryanto meant was Salafi Ilmi or Purist-Salafy that focuses on the purification matter. Out of the Salafi groups, there are Salafi Haraki that call out to nonviolent political activism that also accept some of the IM doctrines in the context of politics and power, and Salafi Jihadi that call out to political action and violence to counter the existing political order to build a Caliphate state (Nisa et al. 2018, 38; Pranawati 2012, 39-40). These three types of Salafis are similar to the variants that were previously mentioned by Azca although they do not use the specific terminology of Salafi named Islam Jihad (Salafi Jihadi), Salafi (Salafi Ilmi), and Politics (Salafi Haraki).

Another transnational ideology that plays a role in the process of religious movements among students is salafism (Nurani 2019). In this case, there are basically two types of salafism. First, it is salafism that acts as a movement for tauheed or monotheism purification; second, it is salafism in a more moderate sense. The first movement was established in Indonesia way longer before the independence day as seen through the Padri movement in West Sumatra in $18 \mathrm{AD}$ and the early $19^{\text {th }}$ century AD (A'La 2008; Chaplin 2018; Hasan 2007). The second movement came to Indonesia in the 1980s. It emerged almost simultaneously with HTI and the Campus Da'wah Institute (LDK) movement implementing IM style in the campuses in Indonesia. This movement is spread in Indonesia as brought by 
the university alumni in Saudi Arabia, Yemen, and Kuwait. This doctrine became even stronger after the establishment of LIPIA (Institute of Islamic and Arabic Sciences) in 1980 in Jakarta. The role of this institution is very significant because it is directly related to the indoctrination process performed on hundreds or even thousands of students who have studied at the institution. At the same time, some LIPIA alumni work as lecturers and ustaz or Islamic studies teacher in various educational institutions, so they help the process of disseminating Salafi ideology to the students in other campuses (Pranawati 2012).

Other than these transnational-influenced movements, local groups have infiltrated the campuses in Indonesia, namely the Indonesian Islamic State (NII) or DI (Darul Islam) group (Haryanto 2019; Pranawati 2012) which Bruinessen mentioned as one of the seeds of radicalism that greatly grew after the New Order. In this case, the results of research published by the Habibie Center confirm that religious movements (Islamism) grown in campuses generally appear in two forms: first, it is the conservatism movement. It is identical with the Campus Da'wah Institute (LDK) and salafism. These groups tend to be scriptural and puritanical despite their relatively different characteristics (Rasyid et al. 2018, 9-11). Second, it is the radicalism movement. It is identical to Hizbut Tahrir Indonesia (HTI) and the Indonesian Islamic State (NII) including ISIS. This group generally rejects Pancasila, democracy and all systems considered to be contrary to Islamic teachings (Marsudi et al. 2019, 15-16; Rasyid et al. 2018). In particular, HTI supports the establishment of a state with a Caliphate system and wishes to have a single system of government worldwide, similar to the objectives of ISIS. As for NII, as the name implies, wants an Indonesian Islamic state system (Haryanto 2018; Rasyid et al. 2018). However, despite the simplifications described by the Habibie Center, in reality, some of these groups are tend to be connected and influence each other in certain contexts (Haryanto 2019). Thus, the intersection between radicalism and college students, historically, occurred gradually until it was formed as it is today.

\section{The Construction of Religious Moderation in Indonesia}

It is recognized that the concept of religious moderation is vulnerable to political interests. However, the moderate Muslim scholars emphasized that the character of Islam is moderate (Ardiansyah 2016; Shihab 2020; Arif 2020; Azra 2020). This view is generally made based on the texts of the 
Quran and the hadiths of the Prophet. In addition, this view also adopts the history of the Prophet's life while he was living in Medina and had the role as the religious figure and leader of a community. Other literatures always mention him as the leader of a state. At that time, the Prophet did not create a state based on Islamic propositions, but it was based on a mutual agreement established by taking into account multi-ethnicity, religions, cultures, and others. This mutual agreement is known as the Medina Charter. Anyone, with any religious belief, can coexist under the Medina charter constitution. The believers of the Jewish religion can continue to carry out their religious beliefs and the believers of the Christian religion can continue to do their worships peacefully without any disturbance. Thus, the concept of moderate Islam, which is always celebrated as an alternative answer to the rampant radicalism grown in campus, seems to be conveying the importance of recognizing Islam, which is moderate since the beginning. In other words, being radical means that it is not in accordance with Islam, which is actually moderate in character.

In fact, there are many arguments from the Quran, the hadith of the Prophet, and the words uttered by the early Islamic generation (the companions and tabi'in) that explain the principles of moderation in Islam, both explicitly and implicitly. These arguments are presented by Yûsuf alQaraḍ̂âi, an Egyptian Muslim scholar who is passionate about wasativah (islamic moderation concept) in the Middle East, at the beginning of his book entitled Figh al-Wasativah (al-Qaradâwî 2009, 1-5). In this context, he wanted to show that moderation has a solid foundation within the classical Islamic tradition, and it is not a thinking that is separable from this tradition. Al-Qaradâwî indeed asserts that moderation is the core of Islamic teaching. It is not a thinking that facilitates (tasâhul) certain matters in religion as alleged by some groups. The wasatiyah method is a method that is obtained from Islamic sources. Those are the Quran, the hadith of the Prophet, and the rules of ushûl al-figh or the principles of Islamic Jurisprudence that prioritizes concession (rukhsah) in furû'(figh), but it is strict in terms of usûl (aqeedah) (Ardiansyah 2016, 237).

In the Indonesian perspective, the word moderate has at least two meanings as stated in the KBBI (The Great of Indonesian Dictionary). First, it means always avoiding extreme behavior or disclosure; and second, it means the tendency towards a dimension or a middle path (KBBI online 2021). Thus, in the Indonesian language, moderate Islam refers to Islam 
that lays itself in the middle (moderate) and is not sided with the any extreme views, both right and left, ifrât (excessive, harsh) and tafrît (underestimate, lenient). Indeed, in Indonesia, the popular understanding of Islam is the concept of Islam that positions itself in the middle path to be attributed to moderate Islam. Thus, Indonesian Islamic moderatism is understood as Islamic religious thinking and practice that lays in the middle path and does not adopt one of the extreme views, Western liberal thinking (left) and radical Islam (right).

However, the word "moderate" used in both Indonesian and the original language (English) is actually not identical with the Arabic translation. This is due to the wide range of meanings the Arabic word holds, "wasatiyah." According to Moderasi Islam (the Islamic Moderation) book written by the team of the Ministry of Religious Affairs, in Indonesian and English, moderate is understood as a normal and moderate behavior or action as described previously. On the other hand, the word moderate (wasatiyah) in Arabic contains three terms that are interconnected with each other. They are wasat (being in the middle of two things), mîzân/wazn (behaving fairly and honestly; not deviating from the determined path), and 'adl (balanced, harmonious, and impartial) (Kementerian Agama RI 2012, 7-14). Firmly, as Shihab stated, the meaning of "middle" or moderate used to explain wasatiyah as it is widely understood actually cannot represent the full nature of moderation taught by Islam (Shihab 2020, 27).

Quraish Shihab, quoting the opinion of Sayyid Qutb, stated that Islam itself is moderation. Islamic teachings are characterized by moderation and its believers must also have a moderate attitude. This moderate attitude is seen in various Muslim behaviors, both in their views and beliefs, thinking and feelings, as well as other terms adhered (Shihab 2020, 35). Furthermore, he utters that moderate Islam or wasatiyah Islam is:

"In all matters of life, both in the world and the hereafter, balance must always be accompanied with the efforts to adapt to the current situation based on Islamic rules and the objective conditions that one faces. Thus, it does not just present two views and then choose what is placed in the middle. Wasathiyah is a balance that is accompanied by the principle of "no shortage and no excess", but at the same time it is not an attitude of avoiding difficult situations or running away from responsibility since Islam teaches Muslims to believe the truth not only actively but also make use of wisdom (Shihab 2020, 43)." 
The Muslim scholar from Egypt, Yûsuf al-Qaraḍâwî explained that Islamic moderation is a moderate attitude (wasatiyah) and justice (ta'âdul) between two opposing sides. In Islamic moderation, no side should dominate and refute the other. The portion taken by each side must be proportional and is not excessive, either it is too much or too little. He also stated that Islamic moderation is not at two extreme views: a group that idolizes the West way too much and accept anything given by them without any criticism, and the other one is a group that likes to make truth claims and forbids many things that are not absolutely haram or forbidden by Islam (read: there is no prohibition argument based on qat $\hat{\imath} \hat{~ o r ~ d e f i n i t i v e ~ t e r m) ~(a l-~}$ Qaraḍ̂uî 2009).

Leaving the two extreme views in religion is the spirit of moderation. Moderate means neither radical nor liberal. This is what the Ministry of Religious Affairs of the Republic of Indonesia emphasizes in the book entitled Moderasi Beragama (Kementerian Agama RI 2019, 7):

"The spirit of religious moderation is to find a meeting point between the two extreme views of religion. On one hand, there are followers of extreme religions who believe in the absolute truth of one interpretation of religious texts and assume that other interpreters are misguided. This group is commonly called the ultra-conservatives. On the other hand, there are also religious people who deifying reason to the point of ignoring the sanctity of religion, or sacrificing the basic beliefs of their religious teachings for the sake of inappropriate tolerance for the followers of other religions. They are commonly called extreme liberals, which need to be moderated."

The description of moderation in the Indonesian context is then based on three pillars, namely moderation of thinking, moderation of movement, and moderation of actions (Kementerian Agama RI 2019, 28). The first pillar, namely moderation of thinking, is related to the thinking that is able to combine text and context. Both must be dynamically put in a dialogue. On one hand, it does not always rely on the text so that it is stuck on its sole textual meaning. Meanwhile, it does not ignore the text and thinks freely without any connection with the text. This mindset can lead to moderate thinking, which then creates an understanding that can combine textual and contextual meaning.

Whereas, the moderation of movement as the second pillar is related to the spreading of religion in any forms must be based on the principle of 
goodness. Da'wah, which is performed by conveying the persuasion to do good deeds or based on goodness ( $\left.m a^{\prime}{ }^{\prime} \hat{u} f\right)$ and refraining oneself from evil (munkar), should consider the method of wisdom, good advice, soothing dialogue, and involves no means of violence. In other words, it should be about eliminating munkar, not creating or leading to new munkar. The third pillar, namely moderation of actions, is more about strengthening the relationship of religion, the culture and traditions of the local community. Religion and culture are not to be confronted and opposed, but they must be brought together so that they can complement each other. Religion does not deny the existence of culture, and culture is not anti-religion either. Islam Nusantara, brought by Nahdlatul Ulama, has found an important position through this moderation of the movement (Mubarok and Rustam 2018; Schmidt 2021).

Furthermore, the Ministry of Religious Affairs (MoRA) also formulates four indicators, which can be used as a guide whether Indonesian citizen is moderate or not, including Muslim, through the book published in 2019 entitled "Moderasi Beragama". Therefore, whatever the religion is, if they follow these four indicators, they are considered moderate (Kementerian Agama RI 2019, 42-47). First, it is nationality commitment. The first indicator has crucial significance in the discourse of Moderate Islam in Indonesia. The loyalty to nationality basic consensus, for instance Pancasila as the state's ideology, challenges to ideology which are contrary to Pancasila, and nationalism become someone's perspective, attitude, and religious behavior called moderate. The thing included as a part of nationality commitment is the acceptance to what has been written in the 1945 Constitution of the Republic of Indonesia and its derivative regulation. All in all, in the nationality commitment, there is a well-known slogan which becomes a faith that is "NKRI harga mati (The Republic of Indonesia: At All Costs!)”.

Second, tolerance is giving space and respecting others' rights to believe, express, and deliver their opinion, even if that person's belief is dissimilar to us. In this context, tolerance is not only about different in religions (inter-religious), but also in beliefs (among those in similar religion or intra-religious). Therefore, within the Islamic community, for example, someone is called moderate if they have tolerance against other beliefs and religious organizations in Islam, beside the tolerance to other people with different religion. By having interreligious tolerance, someone's attitude 
toward other religion's believers can be seen, for example the willingness for dialogue and cooperate, building worship places, and interaction experience with other believers. Meanwhile, the function of intra-religious tolerance that is applied in observing minority beliefs is considered deviated from certain religion.

Third, it is anti-violence or anti-radicalism. Violence or radicalism in this context is an ideology and belief that are willing to make a change toward social system and politics by using violent acts in the name of religion, whether it is mind, verbal, or physical violation. The main point is that radicalism is an act of violence to realize the wanted changes. Therefore, a person is called moderate if he/she gets rid of all violent elements in making the intended changes and instead, uses the peaceful ways, for instance doing something wise, giving good advice, and holding a conciliating dialogue.

Fourth, it is being accommodative toward local culture. It means that moderate attitude is shown by someone's willingness to accept religious practices accommodating local culture and tradition. As long as it does not contradict with the religious principles and lessons, moderate person tends to be kind to accept the tradition and local culture in his/her religious behavior. Indonesia, is a country with various traditions and local culture and makes religion as its infrastructure. By having moderate attitude, a religion will not be seen as the anti of local culture but has mutual advantages. A religion is not comprehended as something rigid, which only uses normative parameter as the truth standard, but it is also based on the virtue.

\section{How does the Higher Education Apply It?}

Haryanto, in his discussion of Islam moderate and nationality movement in the university student community, gives some recommendations which he thinks are applicable as the strategic steps to moderate the student movement in the campus. First, he suggests that the Ministry of Religious Affairs and the Ministry of Research, Technology, and Higher Education to coordinate and collaborate focusing on the program of moderate Islam and nationality stated in the form of The Letter of Collective Resolution (Surat Keputusan Bersama or SKB) of Ministry/Institution. In this program, the two institutions need to coordinate and cooperate with other state institutions (LEMHANAS, TNI, POLRI, BNPT). Furthermore, both ministries should encourage the leaders 
of higher institutions to establish the center of moderate Islam and nationality; improve coaching, do mentoring, and do supervision for various students' activities; involve the community/religious organization and moderate religious figures around the campus or institution. Second, MoRA, through the Agency of Research, Development, Education, and Training (called as Badan Litbang dan Diklat), needs to improve the capacity of Islamic Education lecturer in Public Higher Education and the Religious Counselors as the actor of moderate Islam and nationality movement for student community by providing education and training. The two main points recommended by Haryanto seems practical and relevant to apply in the Higher Religious Institution. This recommendation is a clear emphasis that religion moderation becomes the answer to prevent radicalism, and it is only possible if many parties are involved and work together (Haryanto 2018, 2019).

Haryanto's recommendation is similar to what has been stated by Habibie Center that university should entirely involve in fighting against radicalism and terrorism. The related parties should establish the centers of study and research as an attempt to resist the radicalism and terrorism by prioritizing the moderate and inclusive Islamic lessons and emphasizing the aspects of peace and democracy. To actualize this goal, a university should cooperate with the lecturers, students, and society. In this case, after the finding of seven universities exposed to radicalism, Habibie Center comes up with several policies in preventing radicalism in the higher education. Those are: first, the curriculum restoration, particularly the courses related to nationality and second, listing all staffs, students, and lecturers who are exposed to radicalism. They will be given further guidance and are encouraged to leave the past ideology and return to the Pancasila. If this does not work, they will be given more severe penalty based on the applicable legislation. Third, it issues the regulation to prevent radicalism in the academic environment. Fourth, it issues the regulation to control the dispersion of radicalism in a campus (Rasyid et al. 2018).

In a more systematic way, Habibie Center formulates the above policies into three particular recommendations: first, they are early detection and prevention. It is related to curriculum, in the forms of reparation and revitalization, mainly concerning on nationality courses; publishing special guide to control radicalism in the campus; collaborating with several parties with moderate view to ensure the campus sterilization from radical 
movement; providing the materials regarding the Pancasila, both in religious discussion in the campus mosque, and at the moment of new students' course orientation; conducting a tight selection to whomever delivering or hosting a discussion in the campus mosque. Second, it is about doing surveillance and monitoring. Listing staffs, students, and lecturers suspected of being exposed to radicalism is a part of surveillance and monitoring, it also includes observing students' forum and activities. Third, it is about taking action and/or giving punishment. This step is given for staffs, students, or lecturers suspected of being exposed to radical movement but reluctant to return to the Pancasila ideology (Rasyid et al. 2018). These three things are the steps accommodating the comprehensive-systematic action, practice, and policy.

Furthermore, some strategic policies are taken by the Higher Education, mainly after the abundant discussion mentioning students exposed to radical movement. These policies, generally, refer to those originated from government, the Ministry of Religious Affairs and the Ministry of Research, Technology, and Higher Education which manage several campuses, both public and religious institutions. In Universitas Brawijaya Malang, for instance, they offer a new course i.e. Pembinaan Karakter Berbasis Religi or PKBR (Religion-Based Character Development), which is implemented not only for the connection to divinity but also help students to have professional personality. Universitas Sumatera Utara forbids campus activities carried out after 10 p.m. Institut Pertanian Bogor (IPB) obliges the new students to live in the dormitory, in which they get various religious programs; the students are also placed in a heterogeneous room, in terms of religion, culture, and ethnicity (Rasyid et al. 2018). These policies taken by the mentioned universities show that they positively respond to the ministries' policy, even though in the applicative way, some contra-radicalism policies are different in its emphasis, based on the situation and condition comprehended by the administrator of the higher education (Marsudi et al. 2019).

In line with the aforementioned policies, Purwanto et al. confirms that Universitas Pendidikan Indonesia (UPI) Bandung provides a process or program that internalizes moderate Islam values through the Islamic Education course. This internalization process is done with special pattern, curriculum plan, method, and evaluation. In this case, the Islamic Education course offered is according to the students input, lecturers' skill and competence, and support from UPI environment. Also, the curriculum 
is planned based on the provision of Higher Education. This curriculum is correlated with the establishment process of students' moderate character. In the Semester Lesson Plan based on the curriculum of Islamic Education course of UPI in 2018, for example, there is a content strengthening moderate Islam, such as: a methodology to comprehend Islam, ijtihâd as the process of Islamic law development and various khilâfiyah problems in Islam, moral concept and its application in behavior, da'wah concept, nahi munkar (preventing badness) in Islam, jihad concept in Islam and its embodiment. Meanwhile, the internalization method is applied through face-to-face meeting in a course, tutorial, seminar, and the like. The evaluation is done through screening process of Islamic insight applied in spoken and written forms, and also in regular report from responsible lecturers and tutors (Purwanto et al. 2019). This internalization method emphasizes entirely on the educational aspect and adjusts to the institution's characters as the university of education in Indonesia.

In the context of Islamic moderatism in the Perguruan Tinggi Keagamaan Islam (PTKI or Islamic Higher Education) environment, Maimun and Kosim state that PTKI also considers the development of moderate Islam values as something urgent. One of the main reasons is the threat of radical view which nowadays target the higher education circle, such as students, lecturers, and educational staffs. The leaders of these religious higher educations are fully aware that radicalism is not only spread in public higher educations, but it also starts to enter the environment with religious atmosphere as PTKI. The fact that the religious higher education is contaminated has become a distraction as well as a main challenge of the development of moderate Islam inside the institution. In this context, the challenge, according to Maimun and Kosim, is from the internal campus, which is from students, lecturers, and other educational personnels. It especially happens when there are some of them who hinder the order of exclusive behavior within the student community, both through the code of ethics and other policies. The findings focusing on four religious higher institutions i.e. UIN Sunan Kalijaga Yogyakarta, UIN Mataram, UIN Alauddin Makassar, and IAIN Madura, looks parallel with the findings of radicalism discussion in general that the related people are identical with weak personality from the aspect of religion, so they are easily trapped by the new textual and normative religious understandings (Maimun and Kosim 2019, 148, 153-55). 
The finding of Maimun and Kosim confirms that since the beginning, PTKI has enough capability to improve moderate Islam, in limited scale within the higher education and for society in general. Those capabilities are the sufficient and qualified Human Resources; the strong politic support; one mind in fighting against liberalism and radicalism; row input of students, future lecturers, and educational staffs; and even alumni support, majority of which is from pesantren categorized as Ahl al-Sunnah wa al-Jamâ'ah; the big amount of knowledge of which most of them comes from pesantren has proven to have nationality insight and strong religion, and the environment supporting the improvement of moderate Islam. On one side, Maimun and Kosim acknowledge that PTKI tends to have different conception about moderate Islam even though the substance heads to one similar thing to take the middle position in understanding and applying Islamic teaching; on the other hand, the PTKI, with the big and potential basic capability, can prevent the radicalism development according to the situation and condition they face in real life (Maimun and Kosim 2019). It facilitates implementing government's policy regarding the radicalism.

So far, there is special strategy applied in several PTKIs related to moderate Islam development both in formal academic and informal ways. In formal academic, the policy made by PTKI is establishing curriculum oriented to moderate Islam development, particularly in Islamic course; Islamic study methodology, and strengthening the understanding of religious basis to all campus community. Anticipatory actions have also been done by teaching the new students about moderate Islam and nationality insight, and the narrations of Islamic discussion which brings the spirit of rahmat li alâlamîn. In informal way, PTKI does it by making animation films which has moderate Islam and nationality contents and has millennials as the target. This group is particularly targeted because they are highly vulnerable for being exposed to radicalism. Other things are done by publishing books, texts, and articles in scientific journal with moderate criteria; and other concrete actions. It includes the encouragement to produce the thoughts of figh which are more compatible in Indonesian context covering horizontal issues. Those are nationality, humanity, and ummah (Maimun and Kosim 2019). Some strategic steps in PTKI community are relatively different with the ones done in public higher education, based on the emphasis and the context of each situation and condition. 


\section{Religious Moderation: is it Relevant?}

Many research results confirm the massive of radicalism within student community as shown before. It is even more surprising that not only students of public higher education-which has the minimum amount of critical religious discussions-, but the ones with critical religious background such as UIN and IAIN can also be dragged into radicalism and terrorism. The example is the book bomb 2011 initiated by some alumnis of UIN Syarif Hidayatullah Jakarta, as well as planning to explode a church. If it has yet to happen, then the potential of radicalism and terrorism is actually illustrated clearly (Afrianty 2012; Basri and Dwiningrum 2019; Mubarak 2013; Sirry 2020). It may be the gap between the critical Islamic discussion in PTKI on one hand and radicalism and terrorism on the other hand. All this time, people are sure that students of Public Higher Education, particularly those in exact sciences, science and technology, are more vulnerable toward radicalism and terrorism doctrines compared to those study in PTKI, who are often related to vague vis a vis open and full of nuance perspective (Azra 2020, 105; Sirry 2020, 4), in fact, it does not have to be like that.

Seeing the above fact, religious campuses and its various students' organizations also do the similar thing to prevent radicalism in the higher education. IAIN Kudus, for instance, attempts to teach religious moderation for students by using three strategic step. Those are offering Applied Islamic Science (AIS) as a course, establishing Rumah Moderasi, and holding the AIS classes. Several students' organizations such as PMII, HMI, IMM, and KAMMI in IAIN Surakarta (changed to UIN) also have pivotal role in preventing radicalism, by holding various events, for example, creating Kurikulum Kaderisasi Responsif Radikalisme; internalizing friendly Islamic values through moderate Islam campaign, and maximizing the organization figures as role model; cooperating with other higher educations, and affiliating with the events of intra organization inside campus (Hadziq 2019). This fact strengthens the assumption that moderation program starts to be accepted and applied by students organizations. It shows the optimism that the program, slowly but sure, can erase the radicalism movement which is worrying because it is proven to be a threat to the unity of religious life, nation, and society.

Some strategic steps implemented in various policies in Higher Education are the real actions that, in the scope of sociology and phenomenology, radical movement among students is not caused only by 
one factor (Deny Setiawan 2016; Shaleh et al. 2020; Sumbulah 2017; Weda and Ihsan 2020). The types of radical are also triggered by various factors. Zuly Qodir mentions that there are at least four factors of why someone is willing to do violence in the name of religion. First, it is the understanding of religion; second, it is related to the unfair law enforcement; third, it is related to the injustice of politics, economy, and law in a country; fourth, it is related to educational issues which emphasize more on indoctrination aspect and give no room for certain problem. These four points are considered as the causes which are commonly known by society and academician or intellect (Qodir 2016). The discussion from PPIM (Pusat Pengkajian Islam dan Masyarakat) of UIN Jakarta in 2018 gives the same indication even though, quantitative wise, it does not always lead to the significant implication; sometimes, students' perspective about the basis of state is categorized as radical, but they are against all violent acts, and the like (Nisa et al. 2018). Understanding the dissimilar radical movement factor will lead to realization of the importance of moderation movement which is also not single.

Radicalism trigger among students are complex (Suyanto, Sirry, and Sugihartati 2019; Tahir 2015; Weda and Ihsan 2020). The attempts of moderation are only relevant with this complexity of radicalism. In other words, the significant solution which can be done by campus to prevent the radical movement triggered by the deviate religious understanding is to provide lecturers with moderate religious insight. Besides lecturers, the courses' textbooks, curriculum, and the Semester Lesson Plan of religious courses should be paid more attention because these aspects become the important media in the transmission process of their religious knowledge. The radical movement caused by the massive of transnational movement which scrape the nationalism, can be overcome by deepening the Pancasila, bhinneka (variety), multiculturalism, and so forth. Meanwhile, the religious radical movement triggered by the disappointment toward state politics or even campus, can be prevented by holding an in-depth discussion on various policies which are considered unstable or conducting the full socialization if the problem is because of their misunderstanding; and so on. In short, the mainstream of religious moderatism to prevent radicalism among students needs collaboration of all parties, including religious organization in Indonesia, with varied and contextual strategic model. 
The latest discussions show that some contra-radicalism strategies through moderation implemented in several higher educations seem effective to shape perception and others (Purwasih and Widianto 2020). Nurhayati et al. affirm that the education of Pancasila is effective in preventing radicalism among students of Industrial Engineering Department in Universitas Pamulang. The Education of Pancasila can give the insight to students that radicalism is something deviated giving no advantage to the nation and country (Nurhayati, Indriani, and Utaminingsih 2020). Githa Paradikma also conducts a study about the perception of students of International Class (called as Kelas Khusus Internasional) in IAIN Samarinda. She concludes that the implementation of moderate Islam in the study program is excellent. This is proven by the questionnaire result showing $93.5 \%$. Paradikma says that this perception is caused by their broad understanding about moderate Islam so they realize the importance of the implementation of moderate Islam for the sake of peace (Paradikma 2019).

Religious moderation or moderate Islam is also relevant in the context of inter-sects in Islam, if it is measured with moderate indicator in the perspective of the Ministry of Religious Affairs, it includes in the indicator of intra-religious tolerance. In the previous research, the authors show the urgency of moderate Islam to handle the dispute between Sunnî and Shî̀, both in social conflict in society and-which is quite surprisingconflict in academic environment (Afwadzi and Miski 2020). In the academic environment, Sunnî and Shî‘a conflict also happens. For example, when Jalaluddin Rakhmat, well-known as the leader of Shî́a Indonesia, did his dissertation on sunnah of sahabah (Prophet's companions sunna) in UIN Alauddin Makassar, a group of fundamentalist Islamic scholar came to the campus to demand that Rakhmat's doctorate degree was eliminated. However, UIN Alauddin was tenacious to proceed it because the doctorate degree is a scientific consideration. Ironically, just because their request was rejected by the campus, they then declared that Rakhmat's blood is halal (to kill). Nonetheless, the dissertation process kept progressing and eventually he got the doctorate degree in the Islamic Thought after his Promotion Examination on January 15, 2015 (Afwadzi and Miski 2020, 69). 
Jalaluddin Rakhmat states in the book introduction, which is a part of his dissertation (Rakhmat 2015, 6):

"When an oppose reaction emerged because of this study, when thousands of internet articles claimed me as a liar Syiah, bad Syiah, infidel Syiah, I almost halted this study. But then I remembered Al-Hakim. I am not the first person to be humiliated. I want to present a history as it is 'wie es eigentlich gewesen'..."

In UIN Syarif Hidayatullah Jakarta in 2015, the dissertation of Muhammad Babul Ulum on political hadith among companions which indeed had the similar thinking as Shî‘a, was rejected by the Director of Graduate Program and was not passed the graduation requirement. This dissertation is said "to destroy" the companion's virtues which became 'Alî ibn Abî Tâlib's opposition in the Battle of Jamal (the Camel) and the Battle of Șiffin. The presented data is also anti-mainstream. However, the group ideological interest should not be included in the academic area which should be objective. Babul Ulum writes a "stinging" introduction in a book which is a product of his dissertation (Ulum 2018, 6):

"I am aware of the fact that this book will get rejection from the majority of readers in the motherland. Let alone the non-academician, the academician who has professor degree, and is the Director of Graduate Program, a substitute of Prof. Azra even turned down my dissertation with his very naive words: this kind of dissertation must not be proposed in the promotional exam. He even rejected my research conclusion and also the methodology as well as the sources. In fact, before stating those words, he admitted that he had not entirely read my dissertation. He only read the last part of my research conclusion which is in contradiction with the ideology he inherited from his ancestors... it is even more strange that this professor of ours, initially, did not grant me graduation pass in the promotional exam. In fact, that step is the last process of this dissertation after passing the introduction exam and the four-time working-in-progress (WIP) exam I did which granted me 92 score."

From the explanation above, it can be understood that moderate Islam or religious moderation seems relevant in the higher education and is effective in forming positive perceptions. It is able to eliminate radical thoughts in the world of education in Indonesia. Further, moderate Islam or religious moderation is considered to be able to resolve the Sunnî and 
Shî‘a conflict as one of the problems of religious moderation, including in universities.

\section{Conclusion}

Based on the three main questions: how the construction of religious moderation in Indonesia is; how it is formulated in the strategic policy in the higher education; and the relevance of the religious moderation program in the higher education in Indonesia in the context of contemporary life, this study shows that religious moderation or moderate Islam is believed as Islam itself. In other words, the thinking pattern and attitude which are radical or even leading to terrorism, do not reflect the real Islamic teaching. Religious moderation or moderate Islam is considered as the understanding and religious attitude which is in the middle, not inclined to the right or left. "In the middle" here is then described with four indicators, those are nationality commitment, tolerance, anti-violence, and accommodative toward local culture. From these bases, several recommendations are suggested by some moderate Islam reviewers from students' communities in Indonesian Higher Education. It is then expected to be applied to the particular policies in education world. Furthermore, in the practice, the implementation is done in formal academic and informal way, according to the situation and condition of each environment in the higher education. Additionally, the latest discussion shows that some contra-radicalism strategies through moderation implemented in several higher educations look relevant and effective to establish the positive perception and others.

\section{Acknowledgment}

This article is a part of Litapdimas research in 2021 entitled "Artikulasi Islam Moderat di Kalangan Mahasiswa Muslim dan Implikasinya pada Gerakan Kontra-Radikalisme di Indonesia: Kajian terhadap Perguruan Tinggi Islam di Malang” written by Benny Afwadzi and Miski. Hence, the authors extend their gratitude to The Ministry of Religious Affairs of The Republic of Indonesia for the research funding through Litapdimas Program. The authors also want to thank Lembaga Penelitian dan Pengabdian Masyarakat UIN Maulana Malik Ibrahim Malang handling this program. 


\section{References}

A'La, Abd. 2008. "The Genealogy of Muslim Radicalism in Indonesia: A Study of the Roots and Characteristics of the Padri Movement." Journal of Indonesian Islam 2(2): 267-99.

DOI: https://doi.org/10.15642/jiis.2008.2.2.267-299.

Afrianty, Dina. 2012. "Islamic Education and Youth Extremism in Indonesia." Journal of Policing, Intelligence and Counter Terrorism 7(2): 134-46.

DOI: https://doi.org/10.1080/18335330.2012.719095.

Afwadzi, Benny. 2020. "Membangun Moderasi Beragama di Taman Pendidikan Al-Qur'an dengan Parenting Wasathiyah dan Perpustakaan Qur'ani." Transformasi: Jurnal Pengabdian Masyarakat 16(2): 106-20.

DOI: https://doi.org/10.20414/transformasi.v16i2.2647.

Afwadzi, Benny, and Miski Miski. 2020. Islam Moderat dan Shï'ah Zaydiyah: Kontribusi Pemikiran Hadis Muhammad Ibn Ismā'īl AlSṢan'ānī bagi Moderasi Islam di Indonesia. Malang: UIN-Maliki Press.

Ardiansyah, Ardiansyah. 2016. "Islam Wasațiyah dalam Perspektif Hadis: Dari Konsep Menuju Aplikasi." Mutawatir: Jurnal Keilmuan Tafsir Hadis 6(2): 232-56.

DOI: https://doi.org/10.15642/mutawatir.2016.6.2.232-256.

Arif, Muhammad Khairan. 2020. "Moderasi Islam (Wasathiyah Islam) Perspektif Al-Qur'an, As-Sunnah serta Pandangan Para Ulama dan Fuqaha." Al-Risalah 11(1): 22-43.

DOI: https://doi.org/10.34005/alrisalah.v11i1.592.

Arif, Syaiful. 2020. "Moderasi Beragama dalam Diskursus Negara Islam: Pemikiran KH Abdurrahman Wahid.” Jurnal Bimas Islam 13(1): 73104.

DOI: https://doi.org/10.37302/jbi.v13i1.189.

Arifin, Syamsul. 2020. Utopia Negara Khilafah: Ideologi dan Gerakan Sosial Hizbut Tahrir. Malang: Literasi Nusantara.

Ash-Shallabi, Ali Muhammad. 2020. Wasathiyah dalam Al-Qur'an: Nilai-Nilai Moderasi Islam dalam Akidah, Syariat, Dan Akhlak. Jakarta: Pustaka Al- 
Kautsar.

Azca, Muhammad Najib. 2013. "Yang Muda, Yang Radikal: Refleksi Sosiologis Terhadap Fenomena Radikalisme Kaum Muda di Indonesia Pasca Orde Baru." Jurnal Maarif: Arus Pemikirian Islam dan Sosial 8(1): 14-41.

Azra, Azyumardi. 2020. Relevansi Islam Wasathiyah: dari Melindungi Kampus Hingga Mengaktualisasikan Kesalehan. Jakarta: Kompas Media Nusantara.

Barton, Greg. 2011. Biografi Gus Dur: The Authorized Biography of Abdurrahman Wahid. XI. Yogyakarta: LKiS.

Basri, Basri, and Nawang Retno Dwiningrum. 2019. "Potensi Radikalisme di Perguruan Tinggi (Studi Kasus di Politeknik Negeri Balikpapan)." JSHP : Jurnal Sosial Humaniora dan Pendidikan 3(1): 84-91.

DOI: https://doi.org/10.32487/jshp.v3i1.546.

Bruinessen, Martin Van. 2002. "Genealogies of Islamic Radicalism in PostSuharto." South East Asia Research 10(2): 117-54.

Chaplin, Chris. 2018. "Salafi Activism and the Promotion of a Modern Muslim Identity." South East Asia Research 26(1): 3-20.

DOI: https://doi.org/10.1177/0967828X17752414.

Darajat, Zakiya. 2017. "Muhammadiyah dan NU: Penjaga Moderatisme Islam di Indonesia." Hayula: Indonesian Journal of Multidisciplinary Islamic Studies 1(1): 79-94.

DOI: https://doi.org/10.21009/hayula.001.1.05.

Davids, Nuraan. 2017. "Islam, Moderation, Radicalism, and Justly Balanced Communities." Journal of Muslim Minority Affairs 37(3): 309-20. DOI: https://doi.org/10.1080/13602004.2017.1384672.

Djamil, Abdul. 2011. "Moderasi Gerakan Islam." Dialog : Jurnal Penelitian dan Kajian Keagamaan 71(1): 91.

Hadziq, Abdulloh. 2019. "Nasionalisme Organisasi Mahasiswa Islam dalam Menangkal Radikalisme di Institut Agama Islam Negeri (IAIN) Surakarta." Jurnal Pendidikan Agama Islam Al-Thariqah 4(1): 50-59. DOI: https://doi.org/10.25299/al-thariqah.2019.vol4(1).2791.

Hambali, Yoyo. 2010. "Hukum Bom Bunuh Diri Menurut Islam Radikal 
dan Islam Moderat." Maslahah 1(1): 40-64.

DOI: https://doi.org/10.33558/maslahah.v1i1.1200.

Haryanto, Joko Tri. 2018. "Gerakan Moderasi Islam dan Kebangsaan di

Kalangan Mahasiswa Perguruan Tinggi Umum.” Policy Brief 4(1): 514.

Haryanto, Joko Tri. 2019. Beragama Ala Mahasiswa Milenial. 1st ed. Jakarta Pusat: Litbangdiklat Press.

Hasan, Noorhaidi. 2007. "The Salafi Movement in Indonesia: Transnational Dynamics and Local Development." Comparative Studies of South Asia, Africa and the Middle East 27: 83-94.

DOI: https://doi.org/10.1215/1089201x-2006-045.

Hilmy, Masdar. 2013. "Whither Indonesia's Islamic Moderatism?: A Reexamination on the Moderate Vision of Muhammadiyah and NU." Journal of Indonesian Islam 7(1): 24-48.

DOI: https://doi.org/10.15642/JIIS.2013.7.1.24-48.

Ichwan, Moch Nur. 2013. "Towards a Puritanical Moderate Islam: The Majelis Ulama Indonesia and the Politics of Religious Orthodoxy." In Contemporary Developments in Indonesian Islam Explaining the Conservative Turn, ed. Martin Van Bruinessen. Singapore: ISEAS Publishing, 60-104.

DOI: https://doi.org/10.1355/9789814414579-006.

Kementerian Agama RI. 2019. Moderasi Beragama. Jakarta: Badan Litbang dan Diklat Kementerian Agama RI.

Kementerian Agama RI. 2012. Moderasi Islam (Tafsir Al-Qur'an Tematik). Jakarta: Lajnah Pentashihan Mushaf Al-Qur'an.

Maimun, and Mohammad Kosim. 2019. Moderasi Islam di Indonesia. 1st ed. ed. Faidi Haris. Yogyakarta: LKiS.

Marsudi, Imam et al. 2019. Menangkal Radikalisme di Kampus. eds. Muhammad Turhan Yan et al. Surabaya: Pusat Pembinaan Ideologi Lembaga Penelitian dan Pengabdian kepada Masyarakat Universitas Negeri Surabaya.

Mohammad, Nabil. 2018. "The Role of the Qur'ānic Principle of Wasatiyyah in Guiding Islamic Movements." Australian Journal of 
Islamic Studies 3(2): 21-38. https://ajis.com.au/ index.php/ ajis/ article/view/103.

Mubarak, M. Zaki. 2013. "Dari Semangat Islam Menuju Sikap Radikal: Pemikiran dan Perilaku Keberagamaan Mahasiswa UIN Syarif Hidayatullah Jakarta." Jurnal Maarif: Arus Pemikirian Islam dan Sosial 8(1): 192-217.

Mubarok, Ahmad Agis, and Diaz Gandra Rustam. 2018. "Islam Nusantara: Moderasi Islam di Indonesia." Journal of Islamic Studies and Humanities 3(2): 153-68.

Nisa, Yunita Faela et al. 2018. Gen Z: Kegalauan Identitas Keagamaan. eds. Didin Syafruddin and Ismatu Ropi. Jakarta: PPIM UIN Jakarta.

Nurani, Shinta. 2019. "Salafî Women and Islamic Movements: The Case of Salafism in Jama'ah Al-Khidhir." Ulul Albab: Jurnal Studi Islam 20(2): 233-54.

DOI: https://doi.org/10.18860/ua.v20i2.5666.

Nurdin, Ahmad Ali, Rosihon Anwar, Husnul Qodim, and Usep Dedi Rostandi. 2019. "The Role of Centre for Islamic Thought and Education (CITE): Correcting Negative Image of Islam, Spreading Moderate Islam in Australia." Ulul Albab: Jurnal Studi Islam 20(1): $147-76$.

DOI: https://doi.org/10.18860/ua.v20i1.5589.

Nurhayati, Iin Indriani, and Sri Utaminingsih. 2020. "Efektivitas Mata Kuliah Pendidikan Pancasila dalam Mencegah Radikalisme di Kalangan Mahasiswa Program Studi Teknik Industri Universitas Pamulang." In Prosiding Seminar Nasional Hasil Penelitan $\mathcal{E}$ Pengabdian Kepada Masyarakat 2020 (SENANTIAS 2020), 1, 337-46.

Osman, Mohamed Nawab Mohamed, and Aida Arosoaie. 2020. "Jihad in the Bastion of 'Moderation': Understanding the Threat of ISIS in Malaysia." Asian Security 16(1): 1-14.

DOI: https://doi.org/10.1080/14799855.2018.1470508.

Paradikma, Githa. 2019. "Persepsi Mahasiswa KKI IAIN Samarinda Terhadap Implementasi Islam Moderat.” Tarbiyah Wa Ta'lim: Jurnal Penelitian Pendidikan dan Pembelajaran 6(1): 11-20.

DOI: https://doi.org/10.21093/twt.v6i1.2037. 
Pashentsev, Evgeny N., and Darya Yu Bazarkina. 2021. "ISIS Propaganda on the Internet, and Effective Counteraction." Journal of Political Marketing 20(1): 17-33.

DOI: https://doi.org/10.1080/15377857.2020.1869812.

Pranawati, Rita. 2012. Radikalisme di Kalangan Mahasiswa: Studi Kasus UI dan UIN Jakarta.

Prasetiawati, Eka. 2017. "Menanamkan Islam Moderat Untuk Menanggulangi Radikalisme di Indonesia." Fikri: Jurnal Kajian Agama, Sosial, dan Budaya 2(2): 523-70.

Purwanto, Yedi, Qowaid, Lisa'diyah Ma'rifatanini, and Ridwan Fauzi. 2019. "Internalizing Moderation Value Through Islamic Religious Education in Public Higher Education.” EDUKASI: Jurnal Penelitian Pendidikan Agama dan Keagamaan 17(2): 110-24.

Purwasih, Joan Hesti Gita, and Ahmad Arif Widianto. 2020. "Indication of Radicalism: Students' Perceptions on Pancasila in the Digital Era." In International Conference on Social Studies and Environmental Issues (ICOSSEI 2019), , 137-41.

DOI: https://doi.org/10.2991/assehr.k.200214.023.

al-Qaraḍ̂âî, Yûsuf. 2009. Fiqh Al-Wasațiyah Al-Islāmiyah Wa Al-Tajdīd: Ma'ālim Wa Manārāt. Egypt: Markaz al-Qaraḍāwī li al-Wasaṭiyah alIslāmiyah wa al-Tajdīd. https://www.al-qaradawi.net/node/5066.

Qodir, Zuly. 2016. "Kaum Muda, Intoleransi, dan Radikalisme Agama." Jurnal Studi Pemuda 5(1): 429-45.

Rakhmat, Jalaluddin. 2015. Misteri Wasiyat Nabi Asal Usul Sahabat: Studi Historiografis atas Tarikh Tasyri'. Bandung: Penerbit Misykat.

Rasyid, Imron et al. 2018. Kajian Kontra Terorisme dan Kebijakan: Radikalisme di Perguruan Tinggi Indonesia. Jakarta Selatan.

Salamah, Nur, Muhammad Arief Nugroho, and Puspo Nugroho. 2020. "Upaya Menyemai Moderasi Beragama Mahasiswa IAIN Kudus Melalui Paradigma Ilmu Islam Terapan.” Quality 8(2): 269-90.

DOI: https://doi.org/10.21043/quality.v8i2.7517.

Salik, Mohamad. 2019. "Conserving Moderate Islam in Indonesia: An Analysis of Muwafiq's Speech on Online Media.” Journal of Indonesian 
Islam 13(2): 373-94.

DOI: https://doi.org/10.15642/JIIS.2019.13.2.373-394.

Schmidt, Leonie. 2021. "Aesthetics of Authority: 'Islam Nusantara' and Islamic 'Radicalism' in Indonesian Film and Social Media." Religion 51(2): 237-58.

DOI: https://doi.org/10.1080/0048721X.2020.1868387.

Shaleh, S. et al. 2020. "Formulating Strategies against Student Radicalism: A Case of Madrasah in Indonesia." International Journal of Psychosocial Rehabilitation 24(10).

DOI: https://doi.org/10.37200/IJPR/V24I10/PR300174.

Shifiyuddin, Haris. 2019. "Konstruksi Ideologis Islam Moderat di Lingkungan Kampus: Studi Kasus Ma'had Al-Jami'ah UIN Sunan Ampel." Fikri: Jurnal Kajian Agama, Sosial dan Budaya 4(1): 15-30.

DOI: https://doi.org/10.25217/jf.v4i1.441.

Shihab, M. Quraysh. 2020. Wasathiyah: Wawasan Islam Tentang Moderasi Beragama. Jakarta: Lentera Hati.

Sirry, Mun'im. 2020. "Muslim Student Radicalism and Self-Deradicalization in Indonesia." Islam and Christian-Muslim Relations 31(2): 241-60. DOI: https://doi.org/10.1080/09596410.2020.1770665.

Suhaimi, Suhaimi, and Raudhonah Raudhonah. 2020. "Moderate Islam in Indonesia: Activities of Islamic Da'wah Ahmad Syafii Maarif." Ilmu Dakwah: Academic Journal for Homiletic Studies 14(1): 95-112.

DOI: https://doi.org/10.15575/idajhs.v14i1.8657.

Suharto, Toto. 2014. "Gagasan Pendidikan Muhammadiyah dan NU Sebagai Potret Pendidikan Islam Moderat Di Indonesia." Islamica: Jurnal Studi Keislaman 9(1): 81-109.

DOI: https://doi.org/10.15642/islamica.2014.9.1.81-109.

Sumbulah, Umi. 2017. "De-Radicalisation of Indonesian Students: A Case Study of UIN Malang." Pertanika Journal of Social Sciences and Humanities 25(August): 155-64.

Suyanto, Bagong, Mun'im Sirry, and Rahma Sugihartati. 2019. "PseudoRadicalism and the De-Radicalization of Educated Youth in Indonesia." Studies in Conflict and Terrorism. 
DOI: https://doi.org/10.1080/1057610X.2019.1654726.

Tahir, Masnun. 2015. "The Role of Universities in the Overcoming and Prevention of Terrorist Radicalism and ISIS in the Campus in West Nusa Tenggara." Tasamuh: Jurnal Komunikasi dan Pengembangan Masyarakat Islam IAIN Mataram 13(1): 59-68.

Ulinnuha, Muhammad, and Mamluatun Nafisah. 2020. "Moderasi Beragama Perspektif Hasbi Ash-Shiddieqy, Hamka, dan Quraish Shihab." Suhuf 13(1): 55-76.

DOI: https://doi.org/10.22548/shf.v13i1.519.

Ulum, Muhammad Babul. 2018. Genealogi Hadis Politis Al-Mu'âwiyât dalam Kajian Islam Ilmiah. Bandung: Penerbit Marja.

Wahab, Abdul Jamil. 2019. Islam Radikal dan Moderat: Diskursus dan Kontestasi Varian Islam Indonesia. Jakarta: PT Elex Media Komputindo.

Weda, S, and A Ihsan. 2020. "Religious Radicalism Prevention Efforts Based on Campus Mosque At Higher Education in Makassar Indonesia." PalArch's Journal of Archaeology of Egypt 17(4): 39-57.

Yunanto, Sri. 2018. Islam Moderat vs Islam Radikal: Dinamika Politik Islam Kontemporer. Jakarta: PT Buku Seru. 